\title{
EPIDEMIOLOGY AND RISK FACTORS OF KIDNEY CANCER
}

\author{
Vladimír Janout, Gabriela Janoutová
}

\begin{abstract}
Department of Preventive Medicine, Faculty of Medicine, Palacký University, Hněvotínská 3, 77515 Olomouc, Czech Republic
\end{abstract}

Received: May 15, 2004; Accepted: June 22, 2004

Key words: Kidney cancer/Epidemiology/Risk factors

This review article presents kidney cancer epidemiology as well as main environmental and life style risk factors.

\section{INTRODUCTION}

Kidney cancer is the most important cancer site because of high lethality rates and increasing incidence in some parts of the world mainly among all Caucasian populations and in Japan. There were approximately 189000 kidney cancers in the year 2000 worldwide, two-thirds of which occurred in developed countries ${ }^{1}$ in connection with higher prevalence of different risk factors.

The majority of cancers among adults, which arise in the renal parenchyma, are adenocarcinomas, for the most part of proximal tubular origin, although nephroblastoma occurs in children (Wilms' tumour). Adenocarcinomas may be separated into clear cell and granular cell carcinomas, although the 2 cell types may occur together in some tumors. The distinction between well-differentiated renal adenocarcinomas and renal adenomas can be difficult. The diagnosis is usually made arbitrarily on the basis of size of the mass, but size alone should not influence the treatment approach, since metastases can occur with lesions as small as 0.5 centimeters.

The highest incidence of kidney cancer is observed in the Czech Republic, with rates of approximately 22 per 100000 in men and 11 per 100000 in women. High rates are also observed in Estonia, Hungary, Slovakia, Lithuania, Latvia and Germany (Table 1) and among some black populations of the USA. Conversely, rates up to 10 to 15 times lower are reported in most Asian and African populations and some of South American populations.

The incidence in males is approximately twice that among females in most populations. The incidence of kidney cancer increases logarithmically from the age of 30 years and plateaus around the age of 60-70.

The highest mortality of kidney cancer is reported in the Czech Republic, with rates of approximately 10 per 100000 men and 4.5 per 100000 women. High rates of mortality are also reported in Lithuania, Estonia, Iceland, Latvia, Hungary, Slovakia and Germany (Table 1).

Table 1. Kidney cancer incidence and mortality (world standard) in the year 2000.

\begin{tabular}{|l|c|c|c|c|}
\hline \multicolumn{1}{|c|}{ Country } & \multicolumn{2}{c|}{ Incidence } & \multicolumn{2}{c|}{ Mortality } \\
\hline & Male & Female & Male & 4.53 \\
\hline Czech Republic & 22.25 & 10.86 & 10.09 & 3.66 \\
\hline Estonia & 16.60 & 8.23 & 7.76 & 3.14 \\
\hline Hungary & 15.01 & 7.10 & 6.60 & 2.91 \\
\hline Slovakia & 14.36 & 5.67 & 6.47 & 2.66 \\
\hline Lithuania & 13.86 & 7.19 & 8.17 & 2.44 \\
\hline Uruguay & 13.68 & 5.20 & 6.14 & 2.86 \\
\hline Latvia & 13.34 & 6.47 & 7.33 & 2.92 \\
\hline Germany & 13.02 & 5.91 & 6.27 & 2.47 \\
\hline Iceland & 12.52 & 7.26 & 7.35 & 2.69 \\
\hline Finland & 12.03 & 5.95 & 5.52 & 1.77 \\
\hline Israel & 11.24 & 5.52 & 3.68 & 2.01 \\
\hline USA & 11.15 & 5.95 & 4.19 & 2.12 \\
\hline Canada & 11.04 & 5.76 & 4.02 & \\
\hline
\end{tabular}

GLOBOCAN 2000, Cancer Incidence, Mortality and Prevalence Worldwide, IARC Cancer Base No. 5, Lyon, IARC Press, 2001 
The probability of cure is directly related to the stage or degree of tumor dissemination. Even when regional lymphatics or blood vessels are involved with the tumor, a significant number of patients can achieve prolonged survival and probable cure ${ }^{2}$. When distant metastases are present, disease-free survival is poor, although occasional selected patients will survive after surgical resection of all known tumor. Since a majority of patients are diagnosed when the tumor is still relatively localized and amenable to surgical removal, approximately $40 \%$ of all patients with renal cancer survive 5 years.

This review focuses exclusively on renal cell cancer, because the other urinary cancers (renal pelvis, ureter and urethra) are much rarer and histologically more similar to those of the bladder than the renal parenchyma cancer. Also their aetiology is likely to be more similar to the aetiology of bladder cancer.

Table 2. New cases of cancer in the Czech Republic in the year 2000.

\begin{tabular}{|l|l|l|c|}
\hline Cancer & Male & Cancer & Female \\
\hline Lung & 4905 & Breast & 4598 \\
\hline Colon/Rectum & 4325 & Colon/Rectum & 3130 \\
\hline Prostate & 2695 & Corpus uteri & 1722 \\
\hline Kidney & 1562 & Ovary & 1243 \\
\hline Bladder & 1392 & Lung & 1181 \\
\hline Stomach & 1145 & Cervix uteri & 1069 \\
\hline Pancreas & 829 & Kidney & 1006 \\
\hline
\end{tabular}

GLOBOCAN 2000, Cancer Incidence, Mortality and Prevalence Worldwide, IARC Cancer Base No. 5, Lyon, IARC Press, 2001

Table 3. Kidney cancer incidence in the Czech Republic in the year 2001 (crude) by gender.

\begin{tabular}{|l|r|r|r|r|r|r|r|r|r|r|r|r|r|r|}
\hline & $20-24$ & $25-29$ & $30-34$ & $35-39$ & $40-44$ & $45-49$ & $50-54$ & $55-59$ & $60-64$ & $65-69$ & $70-74$ & $75-79$ & $80-84$ & $85+$ \\
\hline M & 0.5 & 0.7 & 1.1 & 8.5 & 9.2 & 19.9 & 29.8 & 65.8 & 80.5 & 101.6 & 126.5 & 113.4 & 120.7 & 108.8 \\
\hline F & 0.2 & 0.5 & - & 2.1 & 6.4 & 7.9 & 15.6 & 29.1 & 36.5 & 55.5 & 62.1 & 69.0 & 52.1 & 53.3 \\
\hline
\end{tabular}

$\mathrm{M}=$ male

$\mathrm{F}=$ female

Source: ÚZIS ČR, Aktuální informace č.1, 2004

Table 4. Kidney cancer incidence and mortality (crude) in the Czech Republic in the period of 1994-2001.

\begin{tabular}{|c|c|c|c|c|}
\hline Year & \multicolumn{2}{|c|}{ Incidence } & \multicolumn{2}{c|}{ Mortality } \\
\hline & Male & Female & Male & 9.4 \\
\hline 1994 & 26.7 & 18.1 & 14.6 & 8.8 \\
\hline 1995 & 26.7 & 17.6 & 14.1 & 7.8 \\
\hline 1996 & 29.5 & 17.1 & 14.8 & 7.8 \\
\hline 1997 & 28.8 & 17.3 & 13.2 & 8.5 \\
\hline 1998 & 28.6 & 16.7 & 13.9 & 8.1 \\
\hline 1999 & 28.2 & 16.6 & 13.6 & 8.7 \\
\hline 2000 & 26.9 & 17.9 & 14.6 & 9.1 \\
\hline
\end{tabular}

Source: ÚZIS ČR, Aktuální informace č. 1, 2004 


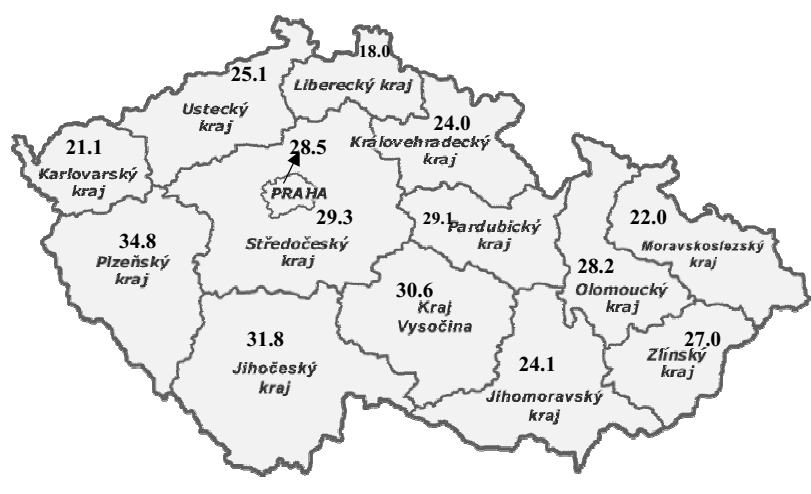

Fig. 1. Geographical distribution of male kidney cancer in the Czech Republic, year 2000 (crude incidence)

\section{SITUATION IN THE CZECH REPUBLIC}

Malignant tumors of the kidney (apart from renal pelvis) account for about $4.5 \%$ of all malignant tumors in the Czech Republic ${ }^{3}$. Kidney cancer is the $4^{\text {th }}$ most common cancer in males and $7^{\text {th }}$ most common cancer in the female population in the Czech Republic (Table 2). The highest incidence in the year 2001 was observed in the age range 65-85 and older in both males and females (Table $3)$. There is no clear-cut trend within the last eight years since 1994 to 2001 in either kidney cancer incidence or mortality (Table 4). As far as geographical distribution of kidney cancer in different regions of the Czech Republic is concerned, the highest incidence is observed in South - Western Bohemia Regions (Plzeňský kraj, Jihočeský kraj and Kraj Vysočina). Conversely the lowest incidence is observed in North - Western Regions (Liberecký kraj, Karlovarský kraj, Moravskoslezský kraj, Královehradecký kraj and Ústecký kraj) of the Czech Republic (Fig. 1).

\section{RISK FACTORS}

Almost all information on risk factors for renal cell cancer has come from case-control studies, conducted in a number of countries in North America, Europe, Australia and Asia.

There are not only life-style risk factors like smoking, diet and obesity, alcohol and other drinks, use of different drugs etc., but environmental risk factors like occupational exposure to different chemicals, radiation, renal dialysis as well, participating probably in the etiology of kidney cancer.

\section{Smoking}

Although results from case-control studies are not entirely consistent, a convincing relation between cigarette smoking and renal cancer has been found ${ }^{4}$. Cohort studies also support this association ${ }^{5}$.

Cigarette smoking has been consistently found to be a moderate risk factor for kidney cancer. Increased risk compared with non-smokers has been observed in the order of 1.2 to 2.3 .

There has been a dose-response relationship demonstrated ${ }^{6}$ with increasing cigarette consumption, with risk for heavy smokers ranging from 2.0 to 3.0. The risk appears to decline with increasing years of smoking cessation $^{7}$.

Population attributable risk estimates indicate that cigarette smoking, both past and present, is responsible for between 27 and $37 \%$ of kidney cancer cases among men, and between 10 and $24 \%$ of cases among women. Approximately half of this attributable risk is due to current smoking.

Another study has reported a suggestive association of passive smoking with renal cell cancer ${ }^{6}$.

\section{Obesity}

Virtually every study that has examined body weight and renal cell cancer has observed a positive association.

Obesity has been consistently linked with kidney cancer, especially among women ${ }^{8}$, with less consistent and weaker results among men ${ }^{9}$. It is not clear what is the mechanism by which obesity causes kidney cancer. Hormonal changes such as increased levels of endogenous estrogens in obese persons may be responsible. Although estrogens induce renal cancer in certain laboratory animals ${ }^{10}$, there is scant epidemiological evidence linking hormone-associated variables to renal cell cancer. Obesity may also predispose to arterionephrosclerosis, which may, in turn render the renal tubules more susceptible to carcinogenesis. Moreover, obesity is sometimes treated with diuretics, which are under evaluation as a potential risk factor (see below).

The population attributable risk of kidney cancer associated with excess weight (defined as being in one of the last three quartiles of body mass index) has been estimated to be over $40 \%$ in women and $5 \%$ in men.

\section{Drugs \\ Analgesics}

Although heavy use of phenacetin-containing drugs has been clearly linked to renal pelvis tumors ${ }^{11}$, an association has been reported also for renal cell cancer ${ }^{12,13}$. Confounding factors do not explain the association because adjustment has been made for cigarette smoking and the use of other types of analgesics.

There have been inconsistent findings on the role of aspirin in the etiology of renal cell cancer. A large-scale study in Minnesota ${ }^{14}$ observed no relation with regular use or duration of use for aspirin, acetaminophen or even phenacetin. But in Denmark, women who were heavy users of phenacetin had a significant five-fold increase in the risk of renal cell cancer ${ }^{15}$. This study also observed no significantly increased risk for aspirin or acetaminophen users.

\section{Diuretics}

Diuretic use has been associated with a five-fold increase in the risk of renal cell cancer among women ${ }^{16}$. 
Adjustment for blood pressure status made little difference, because both hypertensives and non-hypertensives were at elevated risk. Some cohort studies have also linked renal cell cancer with diuretic use ${ }^{17}$. Recent medical records-based case-control studies using prescription data from patients' charts have found three- to four-fold increased risks among women after adjustment for known confounders, including hypertension ${ }^{18,19}$. It is noteworthy that animal studies have linked hydrochlorothiazide and furosemide, the most commonly used diuretics, with tubular cell adenomas and adenocarcinomas of the kidney in rats and hepatocellular tumors in mice ${ }^{20-22}$. Moreover, these compounds act on the renal tubules, the site of origin for renal cell cancers. In many countries of the world, the use of diuretics has increased in the last decades and is especially common among the elderly, so its role, if causal, would have major public health implications as a result of the widespread use of these drugs.

\section{Estrogens}

Although estrogens have induced renal cell carcinomas in laboratory animals, there is little epidemiological evidence supporting an association in humans ${ }^{23}$. Weakly positive findings have been reported for menopausal estrogen use $^{24}$ and oral contraceptives ${ }^{6}$. The relation in humans between hormone-related variables and renal cell cancer remains still unclear.

\section{Hypertension}

Hypertension has also been linked to kidney cancer, although the strength of this relationship has generally been greatly reduced after adjustment for use of diuretics and other antihypertensive drugs. These findings suggest that use of medications may be the primary risk factor and not hypertension per se. Both diuretic and non-diuretic antihypertensive medications have been linked to kidney cancer, with supportive evidence from animal studies. However, identifying whether the real risk is due to the hypertensive state or due to antihypertensive medication has not so far been possible. Whichever of the two is the real risk factor, it is likely to account for a substantial proportion of cases. The attributable risk of reported hypertension or treatment with antihypertensive drugs has been estimated to be $21 \%$ overall, and $39 \%$ among women.

\section{Diet}

\section{High protein consumption}

High protein consumption from meat ${ }^{25}$ and dairy ${ }^{26}$ products has been associated with chronic renal conditions that may predispose to kidney cancer, and has been associated with an increased risk of kidney cancer ${ }^{27}$, although the evidence is inconsistent. There may be some biologic plausibility to a high protein diet affecting risk of renal cell cancer, because animal studies have shown protein intake can induce renal tubular hypertrophy ${ }^{28}$. (On the other hand a possible protective effect has also been identified in a number of studies for high consumption of vegetables).

\section{Coffee, Alcohol, and Other Beverages}

Correlation studies have suggested a relation between the distribution of kidney cancer and per capita consumption of coffee but the finding has not been fully confirmed by case-control studies, when adjustment is made for the confounding effect of cigarette use ${ }^{29}$. Two studies have suggested a positive association. A two-fold risk in both sexes combined was associated with use of decaffeinated coffee without dose-response ${ }^{30}$, while an increased risk for regular coffee use was seen among women only, again with no dose-response relation ${ }^{16}$. On the other hand, the results of a cohort study in Norway, an area of heavy coffee intake, showed a significant inverse trend, with consumers of seven or more cups having one fourth the risk of those drinking two or fewer cups daily ${ }^{31}$. Overall, the results of analytical studies indicate that coffee consumption does not increase the risk of renal cell cancer.

Correlation studies have also reported a relation between per capita intake of alcohol and kidney cancer mortality, but analytical studies of renal cell cancer do not support these findings ${ }^{32}$. The recent Danish casecontrol study observed a statistically significant inverse association of alcohol consumption with renal cell cancer risk $^{4}$. Moreover, cohort studies of alcoholics and brewery workers have reported no excess mortality from kidney cancer $^{33}$.

An increased risk among tea drinkers has been reported in a few studies of renal cell cancer, particularly among women ${ }^{34}$. Also a mortality follow-up of London men revealed a dose-response relation between tea consumption and kidney cancer mortality ${ }^{35}$. In spite of the fact that some teas have been found to be mutagenic and contain tannins that appear carcinogenic in laboratory animals $^{36}$, the etiologic significant of these findings is not clear.

\section{Occupation}

Renal cell cancer is not generally considered an occupationally associated tumor, but an excess risk for renal cell cancer has been observed in a variety of occupations with exposure to:

\section{Asbestos}

Two cohort studies, one of insulators ${ }^{37}$ and one of asbestos products workers ${ }^{38}$ reported significantly elevated mortality rates for kidney cancer. Also an association between asbestos exposure, mostly from work in shipyards, and renal cell cancer was suggested in a Boston-area case-control study ${ }^{39}$. There is some evidence from autopsy surveys and animal studies that asbestos fibers can be deposited in the kidney ${ }^{40}$. Most case-control studies of renal cell cancer have found no association with asbestos exposure, however although their power to detect risks for asbestos exposure is generally low because of the small number of exposed workers.

\section{Polycyclic aromatic hydrocarbons}

Coke and coal oven workers exposed to high levels of polycyclic aromatic hydrocarbons have been reported to 
be at increased risk for kidney cancer ${ }^{41}$. Two case-control studies however observed little excess risk for these workers $^{42,43}$. Also fire-fighters and asphalt and tar workers are exposed to polycyclic aromatic hydrocarbons.

\section{Tetrachloroethylene}

Mortality studies have suggested that laundry and dry cleaning workers may be at increased risk for kidney can$\mathrm{cer}^{44}$. Also case-control studies have indicated an excess risk among dry cleaners ${ }^{43}$. However a large-scale cohort study of these workers showed no increased mortality from kidney cancer ${ }^{45}$. Dry cleaners have been exposed to a large number of chemicals, notably tetrachloroethylene, which has produced hepatocellular carcinomas in laboratory animals ${ }^{11}$.

\section{Gasoline and other petroleum products}

Oil refinery workers and petrol station attendants have been suggested to be at increased risk for kidney cancer. But recent reviews of cohort studies found little or no evidence of an excess risk of kidney cancer ${ }^{46,47}$. Gasoline came under suspicion as a risk factor for renal cell cancer when male rats exposed long-term to vapors of unleaded gasoline developed a significant excess of renal cancers ${ }^{48}$. A number of epidemiological studies have examined the effect of gasoline exposure with inconsistent results ${ }^{42,49-51}$.

Several other occupational associations have been reported like newspaper pressmen, paperboard printing workers, lumberjacks, leather tanners, shoe workers, health care workers, truck drivers, electric power utility workers and architects, with unclear results.

Overall the evidence for associations of kidney cancer with specific occupational exposures is still inconclusive.

\section{Hemodialysis}

There is an increased incidence of acquired cystic disease of the kidney, which predisposes to renal cell cancer among patients undergoing renal dialysis, especially in $\mathrm{men}^{52}$. Although the carcinogenic mechanism is uncertain, some aspect of the uremic process is probably involved during the long-term kidney failure. Some patients with chronic (long-term) kidney failure who are treated with dialysis over a long period of time may develop cysts in their kidneys. Renal cell cancers may develop from the cells that line these cysts.

\section{Radiation}

Ionizing radiation appears to increase the risk of renal cell cancer, especially among patients treated for ankylosing spondylitis and cervical cancer, but the effects are weak $^{53}$. An increased risk has also been described among patients receiving radium 224 for bone tuberculosis and ankylosing spondylitis ${ }^{54}$.

\section{Genetic factors}

Familial clustering of renal cell cancer has been described. Some patients with renal cell cancer may have inherited one or more genes that increase their risk for this disease. The exact function of these genes and how they cause renal cell cancer are not completely known. This hereditary form of renal cell cancer usually occurs in both kidneys and causes multiple tumors to appear. Hereditary forms of renal cell cancer have been found involving both clear cell and papillary cell type renal cell cancer although the specific mutations causing these tumors are different. These observations suggest that the origins of renal cell cancer may involve several tumor suppressor genes on the short arm of chromosome 3 (ref. ${ }^{55}$ ).

Recently, researchers have found gene mutations that cause some rare syndromes such as tuberous sclerosis ${ }^{56}$ and Von Hippel-Lindau ${ }^{57}$. People with these mutations have an increased risk of developing of kidney tumors.

Von Hippel-Lindau syndrome (VHL) is characterized by multiple tumors of the kidneys, brain, spine, eyes, adrenal glands, pancreas, inner ear, or epididymis. Von Hippel-Lindau disease occurs in about 1 in 36,000 births and tends to occur in clusters within families. VHL patients have high incidence of developing clear cell renal cell cancer and the cancers usually develop at an early age. About $40 \%$ of people with this disease have either cysts or tumors in both kidneys. Some can have many small renal cell cancers throughout their kidneys. The gene that causes von Hippel-Lindau disease has been found and is called the VHL gene. It is located on chromosome 3. Tests looking for the VHL gene mutation are becoming available. It has also been shown that a high number of sporadic clear cell renal cell cancer show genetic alterations involving VHL gene thus underscoring the importance of this gene in the pathogenesis of clear cell renal cell cancer.

Tuberous sclerosis is characterized by numerous bumps on the skin (caused by small tumors of the blood vessels), seizures, mental retardation, and cysts in the kidneys, liver and pancreas. Patients with this disease also have an increased risk of developing renal cell cancer.

Some other studies have also shown an association with blood group A.

\section{Other risk factors}

There has been a clear-cut association found between herpes-type virus and renal tumors in the toad. Although nearly all toads carry the infection, only $10 \%$ of animals developed tumors. These findings led to a search in human renal tumors for the evidence of herpes virus proteins. Although herpes simplex proteins were found in the only study reported to date ${ }^{58}$, these observations should be repeated.

\section{PREVENTION}

The main avoidable causes of kidney cancer are cigarette smoking and excess body weight, which together account for up to 50 per cent of all cases ${ }^{59}$. Primary 
prevention in reducing cigarette smoking and obesity are therefore the clearest strategies for reducing the incidence of the disease. A substantial proportion of cases are also likely to be related to hypertension although further information on whether the true risk factor is the disease or the treatment is required in order to clarify implications for prevention ${ }^{60}$.

\section{REFERENCES}

1. Ferlay J, Bray F, Pisani P, Parkin DM. Globocan 2000 - cancer incidence, mortality and prevalence worldwide. IARC Cancer Base No. 5. International Agency for Research on Cancer, Lyon, 2001

2. Sene AP, Hunt L, McMahon RF, Carroll RN. (1992) Renal carcinoma in patients undergoing nephrectomy: analysis of survival and prognostic factors. Br J Urol 70, 125-134

3. ÚZIS ČR, Aktuální informace č. 1, 2004

4. Mellemgaard A, Engholm G, McLauhlin JK, Olsen JH. (1994) Risk of renal cell carcinoma in Denmark. I. Role of socioeconomic status, tobacco use, beverages, and family history. Cancer Causes Control 5, 105-113.

5. McLaughlin JK, Hrubec Z, Heineman EF, Blot WJ, Fraumeni JF, Jr. (1990) Renal cancer and cigarette smoking: 26-year follow-up of U.S. veterans. Public Health Rep 105, 535-537.

6. Kreiger N, Marett LD, Dodds L, Hilditch S, Darlington G. (1993) Risk factors for renal cell carcinoma: results of a population-based case-control study. Cancer Causes Control 4, 101-110.

7. McCredie M, Stewart JH. (1992) Risk factors for kidney cancer in New South Wales: I. Cigarette smoking. Eur J Cancer 28A, 2050-2054.

8. McLaughlin JK, Mandel JS, Blot WJ, Schuman LM, Mehl ES, Fraumeni JF, Jr. (1984) Population-based case-control study of renal cell carcinoma. J Natl Cancer Inst 72, 275-284.

9. McCredie M, Stewart JH. (1992) Risk factors for kidney cancer in New South Wales. II. Urological disease, hypertension, obesity and hormonal factors. Cancer Causes Control 3, 323-331.

10. Newsom GD, Vurgin D. (1987) Etiologic factors in renal cell adenocarcinoma. Semin Nephrol 7, 109-116.

11. International Agency for Research on Cancer. (1987) Over-all Evaluations of Carcinogenicity: An updating of IARC Monographs, Volumes 1 to 42. IARC Monogr Eval Carcinog Risks Hum Suppl 7.

12. McLaughlin JK, Gao Y-T, Gao R-N, Zheng W, Ji B-T, Blot WJ, Fraumeni JF, Jr. (1992) Risk factors for renal cell cancer in Shanghai, China. Int J Cancer 52, 562-565.

13. McCredie M, Stewart JH, Day NE. (1993) Different roles for phenacetin and paracetamol in cancer of the kidney and renal pelvis. Int J Cancer 53, 245-249.

14. Chow W-H, McLaughlin JK, Linet MS, Niwa S, Mandel JS. (1994) Use of analgesics and risk of renal cell cancer. Int J Cancer 59, 467-470.

15. Mellemgaard A, Niwa S, Mehl ES, Engholm G, McLauhlin JK, Olsen JH. (1994) Risk factors for renal cell carcinoma in Denmark. II. Role of medication and medical history. Int J Epidemiol 23, 923-930.

16. Yu MC, Mack TM, Hanesch R, Cicioni C, Henderson BE. (1986) Cigarette smoking, obesity, diuretic use, and coffee consumption as risk factors for renal cell carcinoma. J Natl Cancer Inst 77, 351-356.

17. Lindblad P, McLuaghlin JK, Mellemgaard A, Adami HO. (1993) Risk of kidney cancer among patients using analgesics and diuretics: a population-based cohort study. Int J Cancer 55, 5-9.

18. Finkle WD, McLaughlin JK, Rasgon SA, Yeoh HH, Low JE. (1993) Increased risk of renal cell cancer among women using diuretics in the United States. Cancer Causes Control 4, 555-558.

19. Hiatt RA, Tolan K, Quesenberg CP. (1994) Renal cell carcinoma and thiazide use: a historical case-control study. Cancer Causes Control 5, 319-325.
20. Lijinsky W, Reuber MD. (1987) Pathologic effects of chronic administration of hydrochlorothiazide, with and without sodium nitrate, to 344 rats. Toxicol Ind Health 3, 413-422.

21. National Technology Program. (1989) Toxicology and carcinogenesis studies of furosemide in $\mathrm{F} 344 / \mathrm{N}$ rats and $\mathrm{B} 6 \mathrm{C} 3 \mathrm{~F}$ mice. NTP Technical Report No. 356, Research Triangle Park, North Carolina.

22. National Technology Program. (1989) Toxicology and carcinogenesis studies of hydrochlorothiazide in $\mathrm{F} 344 / \mathrm{N}$ rats and $\mathrm{B} 6 \mathrm{C} 3 \mathrm{~F}$ mice. NTP Technical Report No. 357, Research Triangle Park, North Carolina.

23. McLaughlin JK, Schuman LM. Epidemiology of renal cell carcinoma. In: Lilienfeld AM, editors. Reviews in Cancer Epidemiology. Vol. 2. New York: Elsevier/North Holland, 1983. p. 170-210.

24. Asal NR, Geyer JR, Risser DR, Lee ET, Kadamani S, Cherng N. (1988) Risk factors in renal cell carcinoma. II. Medical history, occupation, multivariate analysis, and conclusion. Cancer Detect Prev 13, 263-279.

25. Maclure M, Willett W. (1990) A case-control study of diet and risk of renal adenocarcinuma. Epidemiology 1, 430-440.

26. McCredie M, Stewart JH. (1988) Risk factors for cancer of the renal parenchyma. Int J Cancer 42, 13-16.

27. Chow W-H, Gridley G, McLaughlin JK, Mandel JS, Wacholder S, Blot WJ, Niwa S, Fraumeni JF, Jr. (1994) Protein intake and risk of renal cell cancer. J Natl Cancer Inst 86, 1131-1139.

28. Smith LJ, Rosenberg ME, Hostetter TH. (1993) Effect of angiotensin II blockade on dietary protein-induced renal growth. An J Kidney Dis 22, 120-127.

29. Partanen T, Heikkila P, Hernberg S, Kauppinen T, Moneta G, Ojajarvi A. (1991) Renal cell cancer and occupational exposure to chemical agents. Scand J Work Environ Health 17, 231-239.

30. Goodman MT, Morgenstern H, Wynder EL. (1896) A case-control study of factors affecting the development of renal cell cancer. Am J Epidemiol 124, 926-941.

31. Jacobsen BK, Bjekle E, Kvale G, Heuch I. (1986) Coffee drinking, mortality, and cancer incidence: results from a Norwegian prospective study. J Natl Cancer Inst 76, 823-831.

32. Brownson RC. (1998) A case-control study of renal cell carcinoma in relation to occupation, smoking, and alcohol consumption. Arch Environ Health 43, 238-241.

33. Adam H-O, McLaughlin JK, Hsing AW, Wolk A, Ekbom A, Holmberg L, Persson I. (1992) Alcoholism and cancer risk: a populationbased study. Cancer Causes Control 3, 419-425.

34. Asal NR, Risser DR, Kadamani S, Geyer JR, Lee ET, Cherng N. (1988) Risk factors in renal cell carcinoma. I. Methodology, demographics, tobacco, beverage use, and obesity. Cancer Detect Prev 11, 359-377.

35. Kinlen LJ, Willows AN, Goldblatt P, Yudkin J. (1988) Tea consumption and cancer. Br J Cancer 58, 397-401.

36. International Agency for Research on Cancer. (1976) Tannic acid and tannins. IARC Monogr Eval Carcinog Risks Hum 10, 253-262.

37. Selikoff IJ, Hammond EC, Seidman H. (1979) Mortality experience of insulation xorkers in th United Sates and Canada, 1943-1976. Ann NY Acad Sci 330, 91-116.

38. Enterline PE, Hartley J, Henderson V. (1987) Asbestos and cancer: a cohort follow-up to death. Am J Ind Med 44, 396-401.

39. Maclure M. (1987) Asbestos and renal adenocarcinoma: a casecontrol study. Environ Res 42, 353-361.

40. Smith AH, Shearn VI, Wood R. (1989) Asbestos and kidney cancer: the evidence supports a causal association. AM J Ind Med 16, 159-166.

41. Redmond CK, Ciocco A, Lloyd JW, Rush HW. (1972) Long-term mortality study of steelworkers. VI. Mortality from malignant neoplasms among coke oven workers. J Occup Med 14, 621-629.

42. Mellemgaard A, Engholm G, McLaughlin JK, Olsen JH. (1994) Risk of renal cell carcinoma in Denmark. IV. Role of occupation. Scand J Work Environ Health 20, 160-165.

43. McCredie M, Stewart JH. (1993) Risk factors for kidney cancer in New South Wales: IV. Occupation. Br J Ind Med 50, 349-354.

44. Brown DP, Kaplan SD. (1987) Retrospective cohort mortality 
study of dry cleaning workers using perchloroethylene. J Occupe Med 29, 535-541.

45. Blair A, Stewart PA, Tolbert PE, Grauman D, Moran FX, Vaught J, Rayner J. (1990). Cancer and other causes of death among a cohort of dry cleaners. Br J Ind Med 47, 162-168.

46. Wong O, Raabe GK. (1989) Critical Review of cancer epidemiology in petroleum industry employees, with a quantitative metaanalysis by cancer site. AM J Ind Med 15, 283-310.

47. International Agency for Research on Cancer. (1989) Occupational exposures in petroleum refining; crude oil and major petroleum fuels. IARC Monogr Eval Carcinog Risks Hum 45, 39-117.

48. MacFarland HN, Ulrich CF, Holdsworth CE. (1984) A chronic inhalation study with unleaded gasoline vapor. J Am Coll Toxicol 3, 231-248.

49. Siemiatycki J, Dewar R, Nadon L, Gerin M, Richardson L, Wacholder S. (1987) Associations between several sites of cancer and twelve petroleum-derived liquids. Scand J Work Environ Health 13 , 493-504.

50. Spirtas R, Stewart PA, Lee JS, Marano DE, Forbes CH, Grauman DJ, Pettigrew HM, Blair A, Hoover RN, Cohen JL. (1991) Retrospective cohort mortality study of workers at an aircraft maintenance facility. I. Epidemiologic results. $\mathrm{Br} \mathrm{J}$ Ind $\mathrm{Med} 48$, $515-530$.

51. Wong O, Harris F, Smith TJ. (1993) Health effects of gasoline exposure. II. Mortality patterns among petroleum refinery workers. Environ Health Perspect 101 (supl 6), 63-76.

52. Ishikawa I. Development of adenocarcinoma and acquired cystic disease of the kidney in hemodialisys patients. In: Miller RW,
Watanabe S, Faumeni JF Jr, et al, editors. Unusual Occurrences as Clues to Cancer Etiology. Tokyo: Japan Scitific Societies Press, 1987. p. 77-86.

53. Boice JD, Engholm G, Kleinerman RA, Blettner M, Stovall M, Lisco H. Moloney WC, Austin DF, Bosch A, Cookfair DL. (1988) Radiation dose and second-cancer risk in patients treated for cancer of the cervix. Radiat Res 116, 3-55.

54. Spiess H, Mays CW, Chmelvesky B. Radium 244 in humans. In: Taylor DM, Mays CW, Gerber GB, editors. Risks from Radium and Thorotrast. BIR Report 21, 1989. p. 7-12.

55. Cohen AJ, Li FP, Berg S, Marchetto DJ, Tsai S, Jacobs SC, Brown RS. (1979) Hereditary renal-cell carcinoma associated with a chromosomal translocation. N Engl J Med 301, 592-595.

56. Choyke PL, Glenn GM, Walther MM, Zbar B, Linehan WM. (2003) Hereditary renal cancers. Radiology 226, 33-46.

57. Pavlovich CP, Schmidt LS. (2004) Searching for the hereditary causes of renal-cell carcinoma. Nat Rev Cancer 4, 381-393.

58. Cocchiara R, Tarro G, Flaminio G, Di Gioia M, Smeraglia R, Geraci D. (1980) Purification of herpes simplex virus tumor associated antigen from human kidney carcinoma. Cancer 46, 1594-1601.

59. Boffetta P, Brennan P, Saracci R. Neoplasms. In: .... Editors. Oxford Textbook of Public Health. Oxford University Press, 2002. p. 1155-1192.

60. McLaughlin JK, Blot WJ, Devesa SS, Fraumeni FJ. Renal cancer. In: Schottenfeld D, Fraumeni JFJ editors. Cancer Epidemiology and Prevention. New York: Oxford University Press, 1996. p. $1142-1155$. 